\title{
A melanoma és az agyi áttétképződés molekuláris háttere
}

\author{
Katona Frida ${ }^{1}$ - Murnyák Balázs ${ }^{1}$ \\ Marko-Varga György ${ }^{2}$ - Hortobágyi Tibor dr. ${ }^{1}$ \\ ${ }^{1}$ Debreceni Egyetem, Általános Orvostudományi Kar, Patológiai Intézet, Neuropatológiai Tanszék, Debrecen \\ ${ }^{2}$ Lund University, Department of Biomedical Engineering, Lund, Svédország
}

\begin{abstract}
A melanoma malignum az egyik legagresszívebb daganat, amely gyakran képez áttétet távoli szervekbe. Az előrehaladott tumorok közel felében figyeltek meg agyi metasztázist. A korai diagnózis a betegség kimenetele szempontjából nagy jelentőségú. Az új, hatékony terápiák kialakításában fontos a bekövetkező genetikai és epigenetikai eltérések feltérképezése, ami ígéretes terápiás célpontokat jelölhet ki. Leggyakrabban a mitogénaktivált proteinkináz útvonal, a foszfatidil-inozitol-3-kináz jelátviteli útvonal és a sejtciklus-szabályozó molekulák génjeinek mutációi vezethetnek melanoma kialakulásához. A melanoma agyi áttétképzésének molekuláris folyamata nem teljesen feltárt. Közleményünkben összefoglaljuk a melanoma, illetve az agyi metasztázis kialakulásában szerepet játszó genetikai eltéréseket és molekuláris mechanizmusokat.
\end{abstract}

Orv Hetil. 2017; 158(28): 1083-1091.

Kulcsszavak: melanoma, áttétképződés, agyi áttét

\section{Molecular background of the melanoma and the brain metastasis}

Malignant melanoma is one of the most aggressive tumors which often gives metastasis to distant organs thereby limiting the chances of survival. Brain metastasis occurs in nearly half of the advanced tumors. In order to improve outcome early diagnosis is important. The discovery and better understanding of genetic and epigenetic changes is essential for developing new effective therapies, which can designate promising therapeutic targets. Melanoma most often is caused by gene mutations of the mitogen-activated protein kinase pathway, the phosphatidylinositol 3-kinase signaling pathway, and the cell cycle regulatory molecules, respectively. The molecular process of brain metastasis has not been fully elucidated. In our review we summarize the genetic alterations and molecular mechanisms playing a role in the development of melanoma and its brain metastasis.

Keywords: melanoma, metastasis, brain metastasis

Katona F, Murnyák B, Marko-Varga Gy, Hortobágyi T. [Molecular background of the melanoma and the brain metastasis]. Orv Hetil. 2017; 158(28): 1083-1091.

(Beérkezett: 2017. április 21.; elfogadva: 2017. május 22.)

\begin{abstract}
Rövidítések
$\mathrm{AKT}=$ szerin $/$ treonin proteinkináz $\beta ; \mathrm{ALM}=$ acrolentiginosus melanoma; $B R A F=$ b-raf protoonkogén, szerin/treonin kináz; $B R M S 1$ = mellrákmetasztázis-szupresszor-1; CCL17 = kemokin C-C motif ligand 17; CCL21 = kemokin C-C motif ligand 21; CCL22 = kemokin $\mathrm{C}-\mathrm{C}$ motif ligand 22; CCR4 = kemokin $\mathrm{C}-\mathrm{C}$ motif receptor 4 ; CCR7 = kemokin $\mathrm{C}$-C motif receptor 7; $C D K 1=$ ciklindependens kináz $1 ; C D K 4=$ ciklindependens kináz 4; CDKN2A = ciklindependens kináz inhibitor $2 \mathrm{~A} ; c-K I T=\mathrm{KIT}$ protoonkogén receptor tirozinkináz; $\mathrm{CSD}=$ chronically sun damaged; CSPG4 = kondroitin-szulfát -
\end{abstract}

proteoglikán-4; Cx26 = konnexin 26; Cx43 = konnexin 43; CXCL12 = kemokin C-X-C motif ligand 12; CXCR4 = kemokin $\mathrm{C}-\mathrm{X}-\mathrm{C}$ motif receptor $4 ; \mathrm{EDNRB}=$ endothelinreceptor- $\beta$; ET3 $=$ endothelin 3; GNAI1 = G fehérje $\alpha 11$ alegység; GNAQ $=\mathrm{G}$ fehérje $\alpha \mathrm{Q}$ alegység; GRIN2A = glutamát ionotróp receptor, NMDA típus 2A alegység; GSH/GSSG = glutation/oxidált GSH; HPSE = heparanáz; IL-23 = interleukin-23; KiSSI = KiSS 1 metasztázis-szuppresszor; LMM = lentigo maligna melanoma; $M A P 2 K 1$ = mitogénaktivált proteinkináz kináz 1 ; $M A P 2 K 2=$ mitogénaktivált proteinkináz kináz $2 ; \mathrm{MAPK}=$ mitogénaktivált proteinkináz; $\mathrm{MClR}=$ melanokortin 1 receptor; 
MED23 = mediátor komplex 23 alegység; $M I T F=$ melanogenezis-asszociált transzkripciós faktor; $\mathrm{MMP2}=$ mátrixmetallopeptidáz-2; MMP9 = mátrixmetalloproteináz-9; $\mathrm{NADP}^{+} /$ $\mathrm{NADPH}=$ nikotinamid-adenin-dinukleotid-foszfát/redukált $\mathrm{NADP}^{+} ; \mathrm{NEDD} 9=$ neuralis prekurzor sejt expresszált, fejlődésileg down-regulált protein $9 ; N F 1=$ neurofibromin $1 ; \mathrm{NF} \kappa \mathrm{B}$ = nukleáris faktor kappa $\mathrm{B} ; \mathrm{NGF}=$ idegnövekedési faktor; $N M 23$ = nukleozid-difoszfát-kináz- $1 ; \mathrm{NMM}=$ nodularis melanoma malignum; NRAS = neuroblastoma RAS virális onkogén homológ; NT-3 $=$ neurotrofin- $3 ; \mathrm{p} 75^{\mathrm{NTR}}=\mathrm{p} 75$ neurotrofin receptor; PI3K = foszfatidil-inozitol-3-kináz; PI3KCA = foszfatidil-inozitol-3-kináz $\alpha$ katalitikus alegysége; PIP2 = foszfatidil-inozitol-4,5-biszfoszfát; PIP3 = foszfatidil-inozitol-3,4,5trifoszfát; PLEKHA5 = pleckstrin homológ domént tartalmazó A család 5-ös tagja; PTEN = foszfatáz és tenzinhomológ; PTPN11 = protein-tirozin foszfatáz, nem receptor típusú 11 ; RAGE $=$ glikozilezett végtermék-specifikus receptor; $\mathrm{RHoC}=$ RAS-homológ család $\mathrm{C}$ tag; ROS = reaktív oxigénformák; RTK $=$ receptor tirozinkináz; S100A4 $=$ S100 kalciumkötő fehérje A4; S100 $\beta$ = S100 kalciumkötő fehérje $\beta$-izoforma; SSM $=$ korai felszínesen terjedő melanoma malignum; $S R C=S R C$ protoonkogén, nem receptor tirozinkináz; STAT3 = jelátvivó és transzkripciós aktivátor 3 ; TGF- $\alpha=$ transzformáló növekedési faktor receptor $\alpha$-izoforma; TGF- $\beta 2=$ transzformáló növekedési faktor receptor $\beta 2$-izoforma; TIMP2 = TIMP metallopeptidáz-inhibitor; TP53 = tumorprotein p53; TrkC = tropomiozin receptor kináz C; TWISTI $=$ twist család $\mathrm{BHLH}$ transzkripciós faktor 1 ; TXNIP = thioredoxin interakciós fehérje; VEGF = vascularis endothelialis növekedési faktor

A melanoma malignum az egyik legagresszívebb daganat. A betegség növekvő incidenciájához exogén, illetve endogén faktorok egyaránt hozzájárulnak. Az exogén faktorok a túlzott mértékű UV-sugárzás és a fokozódó légszennyezés. Az endogén faktorok között szerepelnek különböző szöveti faktorok, vírusok, melaninhoz kötődő gyógyszerek, kozmetikumok, családi anamnézis, DNS-polimorfizmusok és -mutációk, valamint a DNS hibajavító mechanizmusok meghibásodása [1]. A xeroderma pigmentosumban és a dysplasticus naevus szindrómában szenvedő betegeknél gyakoribb a melanoma kialakulása [2].

A melanoma leginkább a felnőtt lakosságot érinti, a diagnosztizált betegek átlagéletkora 40-45 év közé tehető [3]. A tumor progressziója változó, amit egyrészt a tumor genetikai profilja, másrészt az immunrendszer ellenálló képessége okozhat. A korai és pontos diagnózis kulcsfontosságú a betegség kimenetele szempontjából. A korai stádiumban a kezelés elsősorban a sebészi kimetszés [4]. A betegek túlélését és a hatékony kezelés kiválasztását nehezíti a hagyományos terápiákkal szemben mutatott rezisztencia és a fokozott áttétképzési hajlam [5]. A melanoma ugyanis gyakran képez metasztázist a májba, a tüdőbe, a csontokba, a nyirokcsomókba és az agyba [5]. A tüdő- és mellrák után a melanoma a harmadik leggyakoribb agyi áttétet képző tumor [6]. Az előrehaladott melanomák közel felében figyelhető meg agyi áttét. A betegek 30\%-ában a halál oka az agyi áttét prog- ressziója. Boncolási adatok alapján a melanomás betegek 75\%-ánál találtak agyi áttétet [7].

A hatékony terápia kialakításában kiemelt szerepe van a tumor molekuláris hátterének, különösképpen a jelátviteli útvonalak zavarait okozó genetikai és epigenetikai eltérések feltérképezésének. A melanomából kiinduló agyi metasztázis hátterében álló mechanizmusok és genetikai tényezők még nem teljesen ismertek. Közleményünkben összefoglaljuk a melanoma és agyi áttéte molekuláris patológiai jellemzőit.

\section{A melanoma általános jellemzői}

A melanoma malignum elsősorban a bőr, a nyálkahártya, a szem és egyéb szövetek pigmenttermelő festéksejtjeiból (a melanocytákból) kialakuló agresszív daganat [8]. A felnőtt fehér bőrű lakosságot érinti leginkább [3]. Az elmúlt évtizedekben közel kétszeresére emelkedett a diagnosztizált esetek száma. A férfiakban az ötödik, a nőkben a hetedik leggyakrabban diagnosztizált tumor. Az Egyesült Államokban 2014-ben megközelítőleg 76100 új beteget regisztráltak, közülük 9710 eset végződött halállal [9].

A melanoma malignum a klinikai és a szövettani típusa alapján négy osztályba sorolható: 1. korai felszínesen terjedő melanoma (SSM), 2. nodularis melanoma (NMM), 3. lentigo maligna melanoma (LMM), valamint a ritkább klinikai formához tartozó 4 . acrolentiginosus melanoma (ALM) [10]. A cutan formán kívül a nyálkahártya-területeken is kialakulhatnak melanomák (uvealis forma: szemkötőhártya, mucosalis forma: orr- vagy szájnyálkahártya, hüvely, végbél stb.), ahol rejtve vannak $[4,11]$.

A tumor sebészi eltávolítása a korai stádiumban felismert melanomás esetek 90\%-ában eredményes, viszont az előrehaladott és már áttétet adó tumoroknál a sebészi beavatkozás nem bizonyul hatásosnak. Az ilyenkor alkalmazott kemoterápia sugárkezeléssel és immunterápiával egészülhet ki.

Az elmúlt években kiemelt figyelem irányult a genetikai célpontú terápiák felé. A melanomás esetek körülbelül 50\%-ában igazolódott a $B R A F$ (b-raf protoonkogén, szerin/treonin kináz) V600 mutációja, amely elősegíti a MAPK-útvonalon keresztül a melanomasejtek túlélését és proliferációját. A 2011-ben engedélyezett vemurafenib hatóanyagú BRAF-mutációs inhibitor a célzott molekuláris terápiában elsőként alkalmazott szer [10].

\section{A melanoma molekuláris jellemzői}

Az utóbbi évtizedekben, a molekuláris módszerek fejlődésének köszönhetően, lehetővé vált a melanoma hátterében álló genetikai eltérések azonosítása, ami az első nagy lépést jelentette a daganatok molekuláris alosztályainak meghatározásához [12]. A közelmúltban a The Cancer Genome Atlas Network (TCGA) a MAPK-útvonal zavarát okozó génmutációk alapján négy altípust azonosított: a $B R A F$, a $R A S$, az NFI vagy a mindhárom 


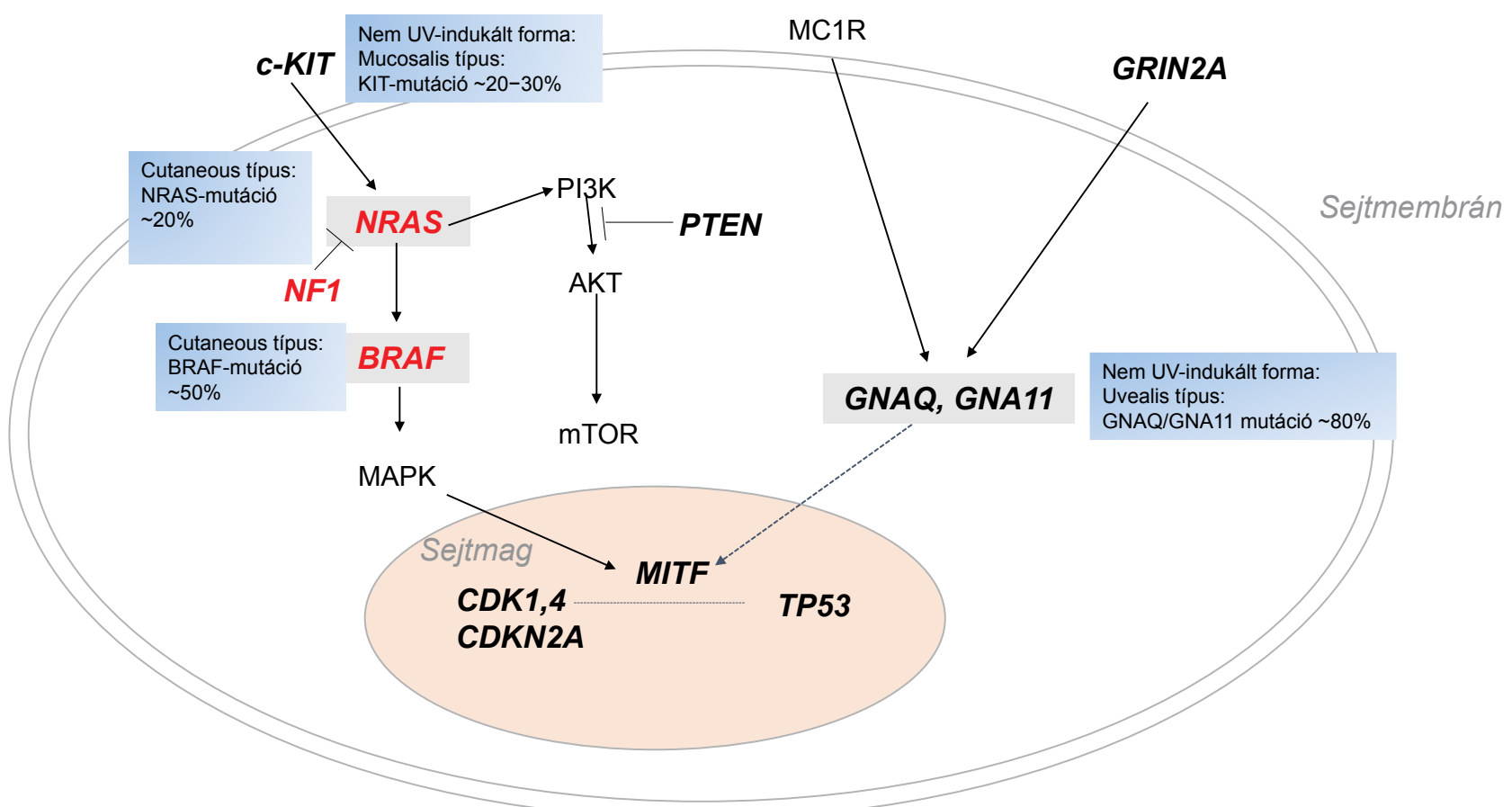

1. ábra

\begin{abstract}
A melanoma malignum hátterében álló molekuláris eltérések. A $B R A F$-, az $N R A S$-, az NFI-, illetve az úgynevezett „triple wild” altípusok. A „triple wild" típusú betegeket a receptor tirozinkinázokban jelentkező mutációk jellemzik. Melanomában a PI3K/AKT a másik fontos jelátviteli útvonal, melyben az AKT-szabályozó PTEN- mutáció figyelhető meg. Megfigyelhető még a melanocytanövekedést szabályozó MITF aktivációs mutációja, az NMDA-receptor egy alegységét kódoló GRINA2 mutációja, vagy a sejtciklus-szabályozásban fontos szerepet betöltő molekulák génjeinek mutációi (CDK1, CDK4, CDKN2A, TP53). A nem UV-indukált, mucosalis forma esetében gyakori a c-KIT aktiváló mutációja, az uvealis forma esetében pedig az MClR jelpálya kis G-fehérje-kódoló génjeinek (GNA11, GNAQ) mutációi

$B R A F=$ b-raf protoonkogén, szerin/treonin kináz; $C D K 1,4=$ ciklindependens kináz 1,$4 ; C D K N 2 A=$ ciklindependens kináz inhibitor $2 \mathrm{~A} ; c-K I T=$ KIT protoonkogén receptor tirozinkináz; $G N A I 1=\mathrm{G}$ fehérje $\alpha \mathrm{ll}$ alegység; $G N A Q=\mathrm{G}$ fehérje $\alpha \mathrm{Q}$ alegység; GRIN2A = glutamát ionotróp receptor, NMDA típus 2A alegység; MAPK = mitogénaktivált proteinkináz; MClR = melanokortin receptor $1 ;$ MITF = melanogenezis-asszociált transzkripciós faktor; NFI = neurofibromin 1; NRAS = neuroblastoma RAS virális onkogén homológ; PI3K/AKT = foszfatidil-inozitol-3-kináz/szerin/ treonin proteinkináz $\beta ; P T E N=$ foszfatáz- és tenzinhomológ; TP53 = tumorprotein p53
\end{abstract}

gén vonatkozásában a nem mutáns (vad) („triple wild”) csoportot [13]. Más kórképekben (például glioblastoma, emlőrák) a hasonló génexpresszió-alapú prognosztikus, diagnosztikus relevanciájú klasszifikáció már korábban megvalósult $[1,14]$.

A genetikai eltéréseket tekintve a melanoma kialakulásában általában a MAPK-útvonal defektusa figyelhető meg [15]. Az UV-indukált melanomában gyakoriak a RAS/RAF kaszkád eltérései: a $B R A F$ (b-raf protoonkogén, szerin/treonin kináz) mutáció $(\sim 50 \%)$ és az NRAS (neuroblastoma RAS virális onkogén homológ) mutáció ( 20\%). A keletkezett mutációk általában a $B R A F$ gén V600 nukleotid pozícióját, illetve az n-RAS fehérje G12, G13 és Q61 kodonjait érintik [16]. Az NFI (neurofibromin 1) tumorszuppresszor a harmadik leggyakrabban mutált gén a melanomában (1. ábra). Egy RAS-GTPáz fehérjét kódol, amely a RAS-GTP hidrolízise révén az inaktív RAS fenntartásáért felel. A MAPK jelátviteli útvonalban részt vevő $M A P 2 K 1$ (mitogénaktivált proteinkináz kináz 1) és a $M A P 2 K 2$ (mitogénaktivált proteinkináz kináz 2) gének a melanomák körülbelül 2-6\%-ában mutáltak [17]. A PTEN (foszfatáz- és tenzinhomológ) mutációja következtében a daganatok többségére a konstitutív PI3K is jellemző. A melanocyták növekedését szabályozó MITF (melanogenezis-asszociált transzkripciós faktor) aktiváló mutációját a melanomák 10-20\%ában írták le. A közelmúltban hat új melanomagént azonosítottak (PPP6C, RAC1, SNX31, TACC1, STK19, $A R I D 2)$, amelyek eltérései szintén kapcsolatba hozhatók a daganatok patogenezisével [18].

Az UV-indukált melanomák egy részében a GRIN2A (glutamát ionotróp receptor, NMDA típus 2A alegység) gén mutációja figyelhető meg. A sejtciklus szabályozásáért felelős gének mutációi is előfordulhatnak: $C D K I$ (ciklindependens kináz 1) 10-20\%; CDK4 (ciklindependens kináz 4) 3\%; CDKN2A (ciklindependens kináz inhibitor 2A) <10\%; TP53 (tumorprotein p53); $<10 \%$ (1. táblázat) [13]. A nem UV-indukált melanoma mucosalis formái esetében gyakori $(\sim 20 \%)$ a melanocytafunkciót szabályozó $c$-KIT (KIT protoonkogén receptor tirozinkináz) gén aktiváló mutációja. Az uvealis forma esetén az MClR (melanokortin 1 receptor) jelpálya kis G-fehérjéit kódoló génekben - a GNAQ (G fehérje $\alpha \mathrm{Q}$ alegység) és a GNA11 (G fehérje $\alpha 11$ alegység) -fordulhat elő mutáció ( 80\%) (1. ábra) [12, 13, 19]. 
1. táblázat A melanoma kialakulásában szerepet játszó gének

\begin{tabular}{|c|c|c|c|}
\hline Szignálútvonal & Gén & Név & Mutációgyakoriság \\
\hline \multirow[t]{5}{*}{ MAPK } & $B R A F$ & B-raf protoonkogén, szerin/treonin kináz & $\sim 50 \%$ \\
\hline & $N R A S$ & Neuroblastoma RAS virális onkogén homológ & $\sim 20 \%$ \\
\hline & $N F 1$ & Neurofibromin 1 & Nem ismert \\
\hline & $M A P 2 K 1, M A P 2 K 2$ & Mitogénaktivált proteinkináz kináz 1,2 & $\sim 2-6 \%$ \\
\hline & $c-K I T$ & KIT protoonkogén receptor tirozinkináz & $\sim 20 \%$ (mucosalis forma) \\
\hline $\mathrm{PI} 3 \mathrm{~K} / \mathrm{AKT}$ & PTEN & Foszfatáz- és tenzinhomológ & $\sim 30-50 \%$ \\
\hline \multirow[t]{4}{*}{ Sejtciklus } & $C D K 1$ & Ciklindependens kináz 1 & $\sim 10-20 \%$ \\
\hline & $C D K 4$ & Ciklindependens kináz 4 & $\sim 3 \%$ \\
\hline & $C D K N 2 A$ & Ciklindependens kináz inhibitor 2A & $<10 \%$ \\
\hline & TP53 & Tumorprotein p53 & $<10 \%$ \\
\hline MClR & $G N A Q, G N A I 1$ & G fehérje $\alpha \mathrm{Q}$ alegység, $\mathrm{G}$ fehérje $\alpha 11$ alegység & $\sim 80 \%$ (uvealis forma) \\
\hline \multirow[t]{2}{*}{ Egyéb } & $G R I N 2 A$ & Glutamát ionotróp receptor, NMDA típus $2 \mathrm{~A}$ alegység & Nem ismert \\
\hline & MITF & Melanogenezis-asszociált transzkripciós faktor & $\sim 12-20 \%$ \\
\hline
\end{tabular}

\section{A metasztázisképzés}

\section{általános mechanizmusa}

Az áttétképződés egy többlépéses folyamat, amelynek során a tumorsejtek a primer helyükról eljutnak távoli szervekbe, ami a betegség túlélését rontja és gyakran halálhoz vezet [5].

A malignus sejtek először lokális proliferációs és migrációs képességre tesznek szert. A tumorsejtek a venulák bazális membránját lebontva az erek lumenébe, majd a véráramláson, illetve a nyirokrendszeren keresztül a távoli szervekhez jutnak. Az extravasatio során a vér- és nyirokkeringésből a környező szövetekbe kerülnek, ahol proliferálnak és angiogenezist indukálnak [20].

$\mathrm{Az}$ áttétképződés limfogén, illetve hematogén terjedéssel jöhet létre (2.ábra). Az intravasatiós folyamat a vérerekben az összetettebb endothelszerkezet miatt eltér a nyirokerektől. A tumorsejtek a lokális invázió után vagy a közeli vérerekbe törnek be, vagy a nyirokcsomóáttéteket ellátó ereket használják a vérrendszerbe történő belépésre [20].

A hematogén áttétképződés során a vérerekbe kerülő tumorsejteket az eltérő nyomásviszonyok miatt különböző mechanikus és immuneffektor hatások érik, amelyek előidézhetik a tumorsejtek számának csökkenését [21]. A tumorsejtek szolúbilis mátrixfehérjék megkötésével mikrothrombust is képezhetnek, amelyben védettek az immunológiai hatásokkal szemben. Ez a fajta áttétképződés szervenként eltérő módon játszódik le. A célszervekben változatos mikrokörnyezettel találkoznak a daganatsejtek (különféle növekedési faktorok, citokinek) [22]. A tumorsejtek vándorlása a szomszédos stromán keresztül három mechanizmussal valósulhat meg: mátrixadhézió, -degradáció (proteolízis) és -migráció. Az extravasatiót követően a távoli áttétek kolóniái sokszor éveken keresztül lappanganak, majd az esetek több- ségében a hormonális hatásra növekedésnek indulnak [23].

Mivel a nyirokerekben a bazális membrán nem folytonos, hanem diszkontinuus és az endothel fenesztrált, a tumorsejtek könnyebben átjutnak az érfalon keresztül a lumenbe. A limfatikus transzport során az immunrendszer sejtjeivel találkoznak, ezért csak az immunrezisztenciával rendelkező tumorsejtek élhetnek túl, amelyek a nyirokáramlás révén jutnak el a nyirokcsomókba. Ott osztódni kezdenek vagy - ha kedvezőtlenek a körülmények - a nyirokcsomók stromájában perzisztálnak [24].

A daganatsejtek autonóm jellege és a metasztatikus környezet további tumorigenikus faktorok. Az agy speciális környezet a metasztázis szempontjából, a nagymértékű szelektivitást biztosító vér-agy gátnak, az agy magas energiafogyasztásának, a magas tápanyagigényének, valamint immunológiailag privilegizált helyzetének köszönhetően [25]. A melanomasejtek metasztázisának utolsó lépéseként a cirkuláló tumorsejtek hozzátapadnak az érfalhoz, majd kikerülve a vér-agy gátat, másodlagos daganatot alakítanak ki az agyi parenchymában [26].

A megnövekedett intracelluláris ROS (reaktívoxigénformák) -szint miatt a sejtekben oxidatív stressz alakul ki, ami összefüggést mutat a metasztatikus potenciállal. A magas ROS-szint a tumor iniciációjában és progressziójában pro- és antitumorigenikus hatású is lehet [27]. A metasztatikus melanomasejtek metabolizmusa megváltozik, redox állapot fenntartásával az oxidatív stresszt túlélik. A metasztatikus gócokban alacsonyabb GSH (glutation) és GSSG (oxidált glutation) arányt figyeltek meg, mint a melanomasejtekben, valamint a $\mathrm{NADP}^{+}$ (nikotinamid-adenin-dinukleotid-foszfát) és a redukáltNADPH-szint magasabb [28]. Az áttéti sejtekben a folsavútvonal aktivitása megnövekszik (magasabb purinszint) [29]. 
A

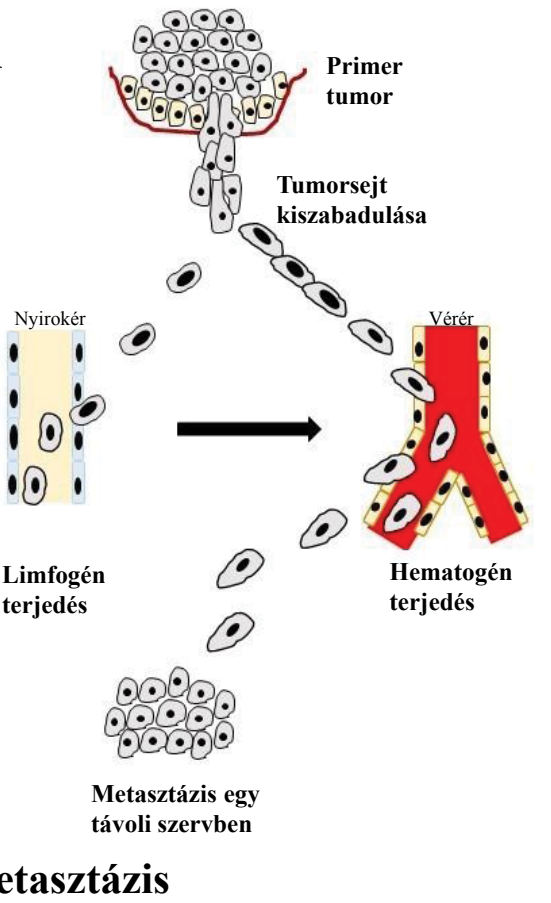

B

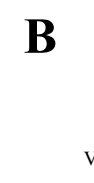

B
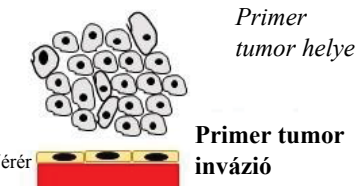

invázió

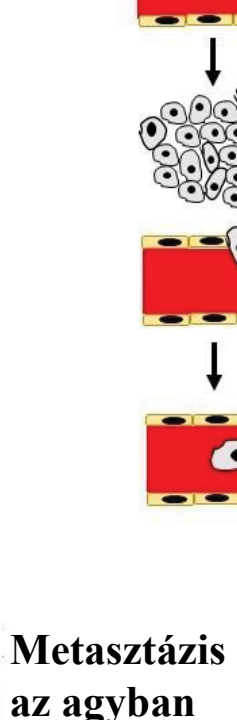

$\therefore$

Intravasatio

- IL-23

- MMP2

- AKT
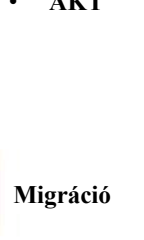

Vér-agy gát
Agy
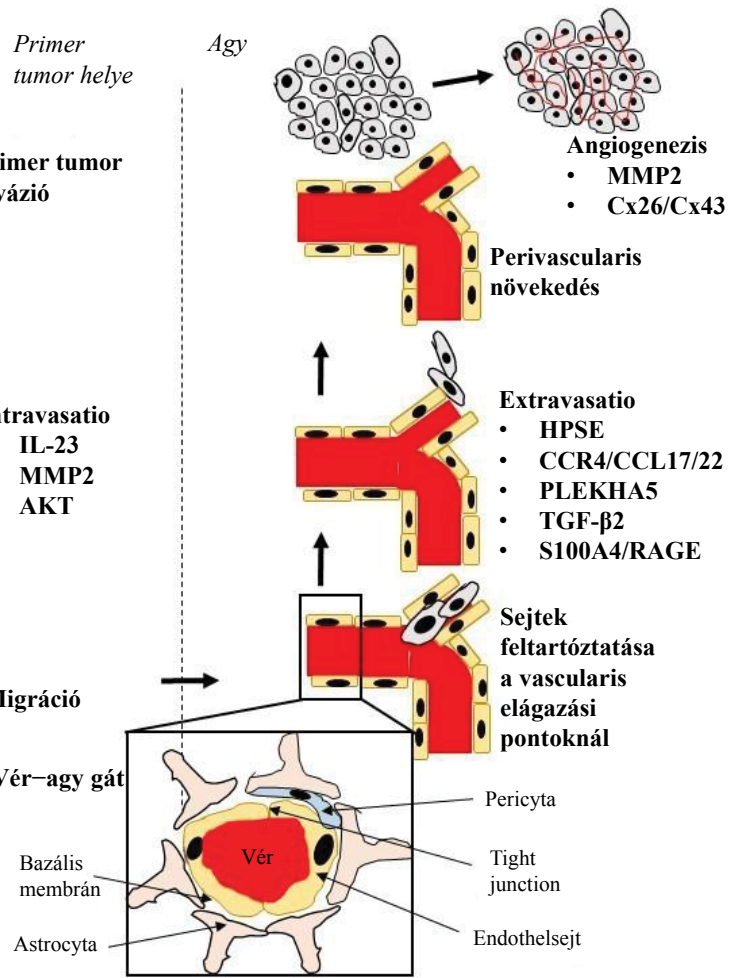

\section{Az agyi melanomametasztázis molekuláris háttere}

A tumorsejtek invázióját és áttétképzését számos gén szabályozza [30]. Az ezekben bekövetkező pontmutációk, deléciók, transzlokációk, amplifikációk, illetve a heterozigótaság elvesztése $(\mathrm{LOH})$ fokozott proliferációhoz és metasztázishoz vezethet. A 2. táblázat összefoglalja a melanoma agyi metasztázisában szerepet játszó géneket. Az agyi áttétre hajlamosító mutációkat a 3. táblázatban foglaltuk össze [31].

A metasztatikus kaszkád folyamatát a következőképpen lehet kategorizálni: 1. Invázió: a tumorsejtek beszűrik a környező szöveteket. 2. Intravasatio: a tumorsejt a vérkeringésbe tör. 3 . Migráció: a tumorsejt a vérkeringés útján terjed. 4. A vascularis elágazási pontoknál a sejtek feltartóztatása. 5. Extravasatio: a sejtek elhagyják az érpályát. 6. Perivascularis növekedés: a daganatsejtek megtelepednek a test távoli helyein és osztódnak. 7. Angiogenezis: a további növekedéshez új erek képződnek [32]. Jelen fejezetben az egyes folyamatokban szerepet játszó molekulákat ismertetjük (2. ábra).
A PI3K/AKT szignalizációs útvonal fokozott aktivitását elôidéző genetikai mutációk általános jelenségek a különféle humán daganatokban (1.ábra). A melanomás betegek több mint 70\%-ában figyelték meg ennek a jelátviteli útvonalnak az onkogenikus elváltozásait, amit kapcsolatba hoznak a betegség progressziójával [33]. Az AKT (szerin/treonin specifikus proteinkináz $\beta$ ) egy fontos szignalizációs molekula. Számos biológiai folyamat szabályozásában részt vesz, mint például a transzkripció, a glükózmetabolizmus, a sejtmigráció, a sejtproliferáció, az apoptózis és az angiogenezis [34]. A PI3K/AKT szignalizációs útvonal hiperaktivációjának számos mechanizmusát írták le a melanomában. Ilyen például az RTK (receptor-tirozinkinázok) amplifikáció, a PI3KCA (foszfatidil-inozitol-3-kináz a katalitikus alegysége) -aktiváló mutáció, a PI3KCA megnövekedett génexpressziója, valamint kópiaszám-amplifikációk és aktiváló mutációk az AKT-ban. A hiperaktivált PI3K/AKT jelátviteli útvonal hátterében álló leggyakoribb mechanizmus a PTEN inaktivációja és deléciója [35]. A PTEN egy lipidfoszfatáz, ami gátolja a PI3K funkcióját a PIP3 (foszfatidil-inozitol-3,4,5-trifoszfát) defoszforilációján keresztül, 
Agyi melanomametasztázis és -invázió kialakulásában szerepet játszó gének

\begin{tabular}{|c|c|c|}
\hline Gén & Név & A kódolt fehérje szerepe, feladata \\
\hline TIMP2 & $\begin{array}{l}\text { TIMP metallopeptidáz- } \\
\text { inhibitor }\end{array}$ & $\begin{array}{l}\text { Megakadályozza az } \\
\text { extracelluláris mátrix túlzott } \\
\text { mértékú degradációját. }\end{array}$ \\
\hline MED23 & $\begin{array}{l}\text { Mediátor komplex } 23 \\
\text { alegység }\end{array}$ & $\begin{array}{l}\text { Az SPl-kötő faktorral együtt } \\
\text { transzkripciós koaktivátorként } \\
\text { múködik. }\end{array}$ \\
\hline TXNIP & $\begin{array}{l}\text { Thioredoxin interakciós } \\
\text { fehérje }\end{array}$ & $\begin{array}{l}\text { A thioredoxininhibíción } \\
\text { keresztül differenciációs faktor. }\end{array}$ \\
\hline NM23 & $\begin{array}{l}\text { Nukleozid-difoszfát- } \\
\text { kináz-1 }\end{array}$ & $\begin{array}{l}\text { A KSR foszforilálása révén } \\
\text { gátolja a MAP } 2 \mathrm{~K} 1, \text { MAP } 2 \mathrm{~K} 2 \\
\text { aktivációját. }\end{array}$ \\
\hline$B R M S I$ & $\begin{array}{l}\text { Mellrákmetasztázis- } \\
\text { szuppresszor-1 }\end{array}$ & $\begin{array}{l}\text { A gap-junction } \\
\text { kommunikációban van szerepe. }\end{array}$ \\
\hline KiSS1 & $\begin{array}{l}\text { KiSS-1 } \\
\text { metasztázisszuppresszor }\end{array}$ & $\begin{array}{l}\text { Metasztinként ismert } \\
\text { G-fehérje-kapcsolt } \\
\text { receptorligand. }\end{array}$ \\
\hline CD44 & CD44 molekula & $\begin{array}{l}\text { Egy integrális sejtmembrán } \\
\text { glikoprotein, amelynek szerepe } \\
\text { van a sejtadhézióban. }\end{array}$ \\
\hline PTEN & $\begin{array}{l}\text { Foszfatáz- és } \\
\text { tenzinhomológ }\end{array}$ & $\begin{array}{l}\text { Az aktinfilamentumokkal } \\
\text { interakcióban idézi eló az } \\
\text { inváziót és a metasztázist. }\end{array}$ \\
\hline PTPNII & $\begin{array}{l}\text { Protein-tirozin foszfatáz, } \\
\text { nem receptor típusú } 11\end{array}$ & $\begin{array}{l}\text { Szabályozza a tirozinfoszfatázt, } \\
\text { a sejtek proliferációját, } \\
\text { differenciációját, motilitását és } \\
\text { apoptózisát. }\end{array}$ \\
\hline$S R C$ & $\begin{array}{l}\text { SRC protoonkogén, } \\
\text { nem receptor } \\
\text { tirozinkináz }\end{array}$ & $\begin{array}{l}\text { Kritikus szerepet tölt be a } \\
\text { celluláris szignáltranszdukciós } \\
\text { útvonalakban: a sejtosztódás, a } \\
\text { motilitás, az adhézió, az } \\
\text { angiogenezis és a túlélés } \\
\text { szabályozásában. }\end{array}$ \\
\hline
\end{tabular}

a PIP3 a PIP2-vé (foszfatidil-inozitol-4,5-biszfoszfát) történő átalakítása csökkenti az AKT kötődését a plazmamembránhoz és szuppresszálja az AKT-foszforilációt. Körülbelül a melanomás esetek 10-30\%-ában epigenetikai csendesítésnek és mutációnak van kitéve a PTEN, amely a foszfo-AKT-szint növekedését eredményezi. A PI3K/AKT szignalizációs útvonal kapcsolatban van a metasztázis több későbbi lépésével, illetve szerepet játszik a sejtadhézió szabályozásában, az extravasatióban, az extracelluláris mátrixfehérjék degradációjában és az angiogenezisben [33].

A hematogén úton terjedő melanomasejtek mozgása akadályozott az érelágazódásoknál [32]. A metasztatikus melanomasejtek az agyi kapillárisokon belül fizikailag elhatárolódnak és erôsebben tapadnak az agyi endotheliumhoz [36].

Különböző adhéziós molekulákat írtak le a leukocytákban és a vérlemezkékben, amelyek segítik a metasztatikus sejtek adhézióját az agyi endotheliumhoz. Ilyenek például a szelektinek, az integrinek vagy a tetraspaninok. Arról azonban keveset tudunk, hogy ezek az adhéziós
3. táblázat $\mid$ A megnövekedett agyi metasztatikus potenciállal összefüggést mutató gének melanomában

\begin{tabular}{lll}
\hline Gén & Név & Szerepe, feladata \\
\hline RHoC & RAS-homológ család & A tumorsejt inváziójában tölt \\
& C tag & be szerepet. \\
& & A morfogenezis és a \\
& motilitás során szabályozza a \\
& & citoskeletalis aktin \\
& & újraszerveződését. \\
\hline
\end{tabular}

elátvivő és transzkripciós Sejtszignalizációs aktivátor 3 transzkripciós faktor. Csökkent expressziója szuppresszálja az agyi metasztázist; gátolja az angiogenezist és a celluláris inváziót.

\begin{tabular}{|c|c|c|}
\hline NEDD 9 & $\begin{array}{l}\text { Neuralis prekurzor sejt } \\
\text { expresszált, fejlődésileg } \\
\text { down-regulált protein } 9\end{array}$ & $\begin{array}{l}\text { Metasztatikus potenciál } \\
\text { kialakítása. }\end{array}$ \\
\hline$M M P 9$ & Mátrixmetalloproteináz-9 & $\begin{array}{l}\text { Az extracelluláris mátrix } \\
\text { degradációjában tölt be } \\
\text { szerepet. }\end{array}$ \\
\hline TWIST1 & $\begin{array}{l}\text { Twist család BHLH } \\
\text { transzkripciós faktor } 1\end{array}$ & $\begin{array}{l}\text { Csökkenti az E-kadherin } \\
\text { közvetítette sejt-sejt } \\
\text { adhéziót, aktiválja a } \\
\text { mesenchymalis markereket és } \\
\text { indukálja a sejtmotilitást. }\end{array}$ \\
\hline$V E G F$ & $\begin{array}{l}\text { Vascularis endothelialis } \\
\text { növekedési faktor }\end{array}$ & $\begin{array}{l}\text { Gátlása csökkenti az agyi } \\
\text { metasztázis kialakulásának az } \\
\text { esélyét, akadályozza a } \\
\text { véredények képződését és a } \\
\text { sejtproliferációt, és angiogén } \\
\text { növekedési faktor. }\end{array}$ \\
\hline
\end{tabular}

molekulák milyen mértékben járulnak hozzá a melanomasejtek agyi metasztázisához [37]. Az extravasatio során a daganatsejtek kilépnek a vérkeringésből [32]. Külső parenchymalis szövetekből származó kemokinek és más, agyból származó ligandumok szabályozzák az agyi erekben terjedő melanomasejtek mozgását. A megfelelő kemokinreceptorok stimulálása megváltozott adhéziós, migrációs, proliferációs és apoptotikus sejtes választ indukálva segíti elő a melanomasejtek kitapadását az intracranialis érrendszer falához, elősegítve a metasztázis kialakulását [26].

A kemokinek szerepét elsősorban a nyirokcsomó és a tüdő metasztázisában írták le [38]. A nyirokcsomókban a CCR7/CCL21 (kemokin C-C motívum receptor 7/ kemokin C-C motívum ligand 21 ) receptor-ligand kötődés járul hozzá a melanomasejtek áttétképződéséhez. A tüdőben a CXCR4/CXCL12 (kemokin C-X-C motívum receptor $4 /$ kemokin $\mathrm{C}-\mathrm{X}-\mathrm{C}$ motívum ligand 12 ) receptor-ligand kölcsönhatás segíti elő a melanomasejtek metasztázisát [39]. Az agyi áttéti tumorsejtekben magasabb szintet mutat a CCR4 (kemokin C-C motif receptor 4) kemokinreceptor, mint a primer melanomasejtekben. Az még nem tisztázott, hogy a CCR4 kemokinreceptor ligandjainak - a CCL17 (kemokin C-C 
motívum ligand 17) és a CCL22 (kemokin C-C motívum ligand 22) - a kötődése segíti-e elő a melanomasejtek agyi metasztázisát [26].

A melanomametasztázist G-fehérje-kapcsolt EDNRBreceptor (endothelinreceptor $\beta$ típus) szabályozza, az ET3 (endothelin 3) ligandja pedig magas expressziót mutat az agyban. Az EDNRB antagonizálása lehetséges klinikai terápia [40].

A melanomasejtekben a $\mathrm{p} 75^{\mathrm{NTR}}$ (p75 neurotrofin receptor) kapcsolatba hozható az agyi metasztázissal. A receptor nagy affinitással köti a neurotrofinokat, például az NGF (idegnövekedési faktor) molekulát. A TrkC (tropomiozin receptor kináz $\mathrm{C}$ ) - ami az NT-3 (neurotrofin-3) feltételezett receptora - génjének expressziója emelkedett a melanomasejtekben, aminek szerepe lehet a melanoma metasztatikus sejtek agyi terjedésében [41]. A TGF- $\beta$ (transzformáló növekedési faktor $\beta$ ) egyik izoformájának, a TGF-ß2 (transzformáló növekedési faktor ß2) molekulának magas endogén expressziója elősegítheti a melanomasejtek agyállományi metasztázisát, míg az alacsony TGF- $\beta 2$-expresszió indukálja az agyi metasztázist az agykamrákban és agyhártyán [42]. Epigenetikai vizsgálatok kimutatták, hogy az shRNS-sel (small hairpin RNS) történő knockdown szabályozás csökkenti a TGF- $\beta 2$ expressziós szintjét, ami gátolja az agyi metasztázist. Ez arra utal, hogy a TGF- 32 -szint szabályozása befolyásolja a melanomasejtek metasztázisát. A csökkent miRNS-328 (rövid nem kódoló RNS) -szint a TGF- 32 expresszió fokozódását eredményezi a humán melanoma-sejtvonalakban [43]. A jövőbeli kutatások ígéretes témája, hogy a miRNS-328-expresszió miként befolyásolja a TGF- $\beta 2-n$ keresztül az agyi melanomametasztázis kialakulását [43].

A metasztatikus daganat kialakulásának feltétele, hogy a tumorsejtek átjussanak a vér-agy gáton. Ennek mechanizmusa a melanomasejtek vonatkozásában még nem tisztázott [44]. A heparanáz (HPSE) a proteoglikánok heparán-szulfát glükózaminoglikán oldalláncait bontó enzim. A heparanáz enzim fokozza a melanomasejtek invázióját az agyszövetben. Az agyi áttétes melanomasejtek astrocytákkal való inkubálása emelkedett heparanázenzim-aktivitást eredményez [45]. Ugyanakkor az agyi eredetû neurotrofinok, mint például az NGF, fokozza a heparanáz enzim aktivitását, és a melanomasejtek migrációja és adhéziója akadályozott a miRNS-sel történő heparanázgátlás révén. Azt még nem sikerült bizonyítani, hogy a heparanáz az agyi melanomametasztázis vonatkozásában terápiás célpont [46].

Néhány közlemény megemlíti a Cx26 (konnexin 26) és a Cx43 (konnexin 43) szerepét. Ezek melanocytákban kifejeződő gap junction fehérjék, amelyeknek szerepük lehet a melanoma agyi metasztázisában $[47,48]$. Egérsejtvonalakban a Cx26 fehérje génjének kiütésével gátolták a melanomasejtek extravasatióját. Sargen és mtsai
(2013) jóindulatú naevusokból, illetve melanomából származó formalinfixált paraffinba ágyazott mintákon vizsgálták a $\mathrm{Cx} 43$ és a Cx26 fehérjék szintjét immunhisztokémiai módszerrel. A melanomás betegek mintái magasabb $\mathrm{Cx} 43$-expressziót mutattak, mint a naevusokból származó minták, míg a Cx26 fehérje szintje alacsony volt [49], ami arra utal, hogy a Cx43 fokozott expressziója csökkenti a melanoma proliferációs és metasztázist kialakító képességét az indukáló TGF- $\alpha$ (transzformáló növekedési faktor $\alpha$ ) mediálta apoptózis révén [50].

Az extracelluláris S100A4 (S100 kalciumkötő protein A4) molekula emelkedett szintje csökkenti a tight junction integritását humán melanomasejtekben [51]. A melanomasejtek S100A4 fehérjét választanak ki, amely parakrin módon kötődik receptorához. Ez a RAGE (glikozilezett végtermék-specifikus receptor) molekulán keresztül képessé teszi endothelsejteken keresztül történő migrációjukat [52]. Az S100A4/RAGE jelátvitelt több más tumorban is összefüggésbe hozták promigrációs, invazív és metasztatikus folyamatokkal. Pajzsmirigyrákban a diaphanous, prosztatarákban a $\mathrm{NF} k \mathrm{~B}$ (nukleáris faktor kappa B), végbélrákban a MAPK/ERK utak aktiválódnak. Kérdéses, hogy ezen útvonalak közül melyik szabályozza az S100A4/RAGE parakrin jelátvitelt (ami elősegíti a melanoma terjedését). Az S100A4 stimulálja a MMP9 (mátrixmetallopeptidáz-9) termelődését és szekrécióját, ami az extracelluláris mátrix lebontása révén járulhat hozzá a melanoma terjedéséhez [53]. A PLEKHA5 (pleckstrin homológ domént tartalmazó A család 5-ös tagja) gátlása akadályozza a melanomasejtek átjutását a vér-agy gáton [53].

Az agyi metasztatikus melanomasejtek IL-23 (interleukin-23) citokint fejeznek ki, ami elősegíti az MMP2 (mátrixmetalloproteináz-2) -szekréciót [54]. Az MMP2termelődés a IV-es típusú kollagén degradációja által fokozza a melanomasejtek extravasatióját. Mindezek elősegítik az extracelluláris mátrix lebontását, megkönnyítve a melanomasejtek átjutását a vér-agy gáton [54]. Az agyban a TGF- $\beta 2$ szintén szabályozza az endothelsejtréteg permeabilitását, befolyásolva a melanomasejtek extravasatióját. A TGF- $\beta 2$ csökkenti az endothel barrier feszülését a szabályozott MMP-szekréción és a down-regulált tight junction fehérjéken keresztül [55].

\section{Következtetés}

A melanoma gyakran ad áttétet, különösen gyakran az agyba. Az agyi áttéti tumorsejteknek a vér-agy gát védelmező környezetet biztosít a kemoterápiás szerekkel és antitumorális immunsejtekkel szemben, segítve a tumorsejtek túlélését és proliferációját. A vér-agy gáton keresztül történő tumorsejt-migráció molekuláris hátterének megértése fontos, mivel az terápiás célpontokra deríthet fényt. 
Anyagi támogatás: A közlemény a Nemzeti Agykutatási Program (NAP) (KTIA_13_NAP-A-II/7.; KTIA_13_ NAP-A-V/3.), az Új Nemzeti Kiválóság Program (ÚNKP-16-3) és a GINOP-2.3.2-15-2016-00043 támogatásával valósult meg.

Szerzői munkamegosztás: A kézirat megszövegezésében mind a négy szerzô részt vett, a kézirat végleges változatát valamennyien elolvasták és jóváhagyták.

Érdekeltségek: A szerző́knek nincsenek érdekeltségeik.

\section{Irodalom}

[1] Ragnarsson-Olding BK. Primary malignant melanoma of the vulva - an aggressive tumor for modeling the genesis of non-UV light-associated melanomas. Acta Oncol. 2004; 43: 421-435.

[2] Hammer H, Tóth-Molnár E, Oláh J, et al. Relationship of the uveal melanoma and the dysplastic naevus syndrome. [Az uvealis melanoma és a dysplasticus naevus-syndroma kapcsolata.] Magy Onkol. 2005; 49: 15-18. [Hungarian]

[3] Berwick M, Buller DB, Cust A, et al. Melanoma epidemiology and prevention. Cancer Treat Res. 2016; 167: 17-49.

[4] Oláh J. Modern diagnosis and treatment of the melanoma malignum. [A melanoma malignum korszerü diagnózisa és kezelése.] Lege Artis Med. 2005; 15: 525-534. [Hungarian]

[5] Braeuer RR, Watson IR, Wu CJ, et al. Why is melanoma so metastatic? Pigment Cell Melanoma Res. 2014; 27: 19-36.

[6] Ajithkumar T, Parkinson C, Fife K, et al. Evolving treatment options for melanoma brain metastases. Lancet Oncol. 2015; 16 e486-e497.

[7] Fedorcsák I, Sipos L. Treatment of brain melanoma metastases. [Agyi melanomaáttétek kezelése.] Magy Onkol. 2003; 47: 109112. [Hungarian]

[8] Shain AH, Bastian BC. From melanocytes to melanomas. Nat Rev Cancer 2016; 16: 345-358.

[9] Weinstein D, Leininger J, Hamby C, et al. Diagnostic and prognostic biomarkers in melanoma. J Clin Aesthet Dermatol. 2014; 7: 13-24.

[10] Karagiannis P, Fittall M, Karagiannis SN. Evaluating biomarkers in melanoma. Front Oncol. 2015; 4: 383.

[11] Balch CM, Gershenwald JE, Soong SJ, et al. Final version of 2009 AJCC melanoma staging and classification. J Clin Oncol. 2009; 27: 6199-6206.

[12] Cirenajwis H. Molecular subtypes of melanoma. Biological and clinical significance. Doctoral dissertation. Lund University, Faculty of Medicine, Lund, 2016.

[13] The Cancer Genome Atlas Network: Genomic classification of cutaneous melanoma. Cell 2015; 161: 1681-1696.

[14] Dai X, Li T, Bai Z, et al. Breast cancer intrinsic subtype classification, clinical use and future trends. Am J Cancer Res. 2015; 5 : 2929-2943.

[15] Tsao H, Chin L, Garraway LA, et al. Melanoma: from mutations to medicine. Genes Dev. 2012; 26: 1131-1155.

[16] Davies H, Bignell GR, Cox C, et al. Mutations of the BRAFgene in human cancer. Nature 2002; 417: 949-954.

[17] Nikolaev SI, Rimoldi D, Iseli C, et al. Exome sequencing identifies recurrent somatic $M A P 2 K 1$ and $M A P 2 K 2$ mutations in melanoma. Nat Genet. 2011; 44: 133-139.

[18] Hodis E, Watson IR, Kryukov GV, et al. A landscape of driver mutations in melanoma. Cell 2012; 150: 251-263.

[19] Vidwans SJ, Flaherty KT, Fisher DE, et al. A melanoma molecular disease model. PLoS One 2011; 6: el8257.

[20] Nguyen DX, Bos PD, Massagué J. Metastasis: from dissemination to organ-specific colonization. Nat Rev Cancer 2009; 9: 274-284.
[21] Wong SY, Hynes RO. Lymphatic or hematogenous dissemination: how does a metastatic tumor cell decide? Cell Cycle 2006; 5: 812-817.

[22] Pantel K, Brakenhoff RH. Dissecting the metastatic cascade. Nat Rev Cancer 2004; 4: 448-456.

[23] Joyce JA, Pollard JW. Microenvironmental regulation of metastasis. Nat Rev Cancer 2009; 9: 239-252.

[24] Tímár J, Csuka O, Remenár E, et al. Progression of head and neck squamous cell cancer. Cancer Metastasis Rev. 2005; 24: 107-127.

[25] Zhang C, Yu D. Microenvironment determinants of brain metastasis. Cell Biosci. 2011; 1: 8 .

[26] Kircher DA, Silvis MR, Cho JH, et al. Melanoma brain metastasis: Mechanisms, models, and medicine. Int J Mol Sci. 2016; 17: pii: E1468.

[27] Schumacker PT. Reactive oxygen species in cancer: a dance with the devil. Cancer Cell 2015; 27: 156-157.

[28] Filomeni G, Rotilio G, Ciriolo MR. Cell signaling and the glutathione redox system. Biochem Pharmacol. 2002; 64: 10571064

[29] Cazes A, Ronai ZA. Metabolism in melanoma metastasis. Pigment Cell Melanoma Res. 2016; 29: 118-119.

[30] Mareel M, Oliveira MJ, Madani I. Cancer invasion and metastasis: interacting ecosystems. Virchows Arch. 2009; 454: 599-622.

[31] Rahmathulla G, Toms SA, Weil RJ. The molecular biology of brain metastasis. J Oncol. 2012; 2012: 723541.

[32] Kienast Y, von Baumgarten L, Fuhrmann M, et al. Real-time imaging reveals the single steps of brain metastasis formation. Nat Med. 2010; 16: 116-122.

[33] Davies MA, Stemke-Hale K, Lin E, et al. Integrated molecular and clinical analysis of AKT activation in metastatic melanoma. Clin Cancer Res. 2009; 15: 7538-7546.

[34] Liang J, Slingerland JM. Multiple roles of the PI3K/PKB (Akt) pathway in cell cycle progression. Cell Cycle 2003; 2: 336-342.

[35] Davies MA, Stemke-Hale K, Tellez C, et al. A novel AKT3 mutation in melanoma tumours and cell lines. Br J Cancer 2008; 99: $1265-1268$.

[36] Molnár J, Fazakas C, Haskó J, et al. Transmigration characteristics of breast cancer and melanoma cells through the brain endothelium: Role of Rac and PI3K. Cell Adh Migr. 2016; 10: 269-281.

[37] Wilhelm I, Molnár J, Fazakas C, et al. Role of the blood-brain barrier in the formation of brain metastases. Int J Mol Sci. 2013; 14: 1383-1411.

[38] Sarvaiya PJ, Guo D, Ulasov I, et al. Chemokines in tumor progression and metastasis. Oncotarget 2013; 4: 2171-2185.

[39] Murakami T, Cardones AR, Hwang ST. Chemokine receptors and melanoma metastasis. J Dermatol Sci. 2004; 36: 71-78.

[40] Saldana-Caboverde A, Kos L. Roles of endothelin signaling in melanocyte development and melanoma. Pigment Cell Melanoma Res. 2010; 23: 160-170.

[41] Denkins Y, Reiland J, Roy M, et al. Brain metastases in melanoma: roles of neurotrophins. Neuro-Oncol. 2004; 6: 154-165.

[42] Zhang C, Zhang F, Tsan R, et al. Transforming growth factor- $\beta 2$ is a molecular determinant for site-specific melanoma metastasis in the brain. Cancer Res. 2009; 69: 828-835.

[43] Li JR, Wan, JQ, Gong Q, et al. MicroRNA-328 inhibits proliferation of human melanoma cells by targeting TGF 32 . Asian Pac J Cancer Prev. 2015; 16: 1575-1579.

[44] Abbott NJ, Patabendige AA, Dolman DE, et al. Structure and function of the blood-brain barrier. Neurobiol Dis. 2010; 37: $13-25$.

[45] Marchetti D, Li J, Shen R. Astrocytes contribute to the brainmetastatic specificity of melanoma cells by producing heparanase Cancer Res. 2000; 60: 4767-4770.

[46] Vlodavsky I, Goldshmidt O, Zcharia E, et al. Mammalian heparanase: involvement in cancer metastasis, angiogenesis and normal development. Semin Cancer Biol. 2002; 12: 121-129. 
[47] Ito A, Katoh F, Kataoka TR, et al. A role for heterologous gap junctions between melanoma and endothelial cells in metastasis. J Clin Invest. 2000; 105: 1189-1197.

[48] Hsu M, Andl T, Li G, et al. Cadherin repertoire determines partner-specific gap junctional communication during melanoma progression. J Cell Sci. 2000; 113: 1535-1542.

[49] Sargen MR, Gormley RH, Pasha TL. Melanocytic tumors express connexin 43 but not 26: Immunohistochemical analysis with potential significance in melanocytic oncogenesis. Am J Dermatopathol. 2013; 35: 813-817.

[50] Tittarelli A, Guerrero I, Tempio F, et al. Overexpression of connexin 43 reduces melanoma proliferative and metastatic capacity. Br J Cancer 2016; 115: el4. Correction to: Br J Cancer 2015; 113: 259-267.

[51] Herwig N, Belter B, Wolf S, et al. Interaction of extracellular S100A4 with RAGE prompts prometastatic activation of A375 melanoma cells. J Cell Mol Med. 2016; 20: 825-835.

[52] Hernández JL, Padilla L, Dakhel S, et al. Therapeutic targeting of tumor growth and angiogenesis with a novel anti-S100A4 monoclonal antibody. PloS One 2013; 8: 72480 .
[53] Jilaveanu LB, Parisi F, Barr ML, et al. PLEKHA5 as a biomarker and potential mediator of melanoma brain metastasis. Clin Cancer Res. 2015; 21: 2138-2147.

[54] Klein A, Schwartz H, Sagi-Assif O, et al. Astrocytes facilitate melanoma brain metastasis via secretion of IL-23. J Pathol. 2015; 236: 116-127.

[55] Ishihara H, Kubota H, Lindberg RL, et al. Endothelial cell barrier impairment induced by glioblastomas and transforming growth factor $\beta 2$ involves matrix metalloproteinases and tight junction proteins. J Neuropathol Exp Neurol. 2008; 67: 435448.

(Hortobágyi Tibor dr., Debrecen, Nagyerdei krt. 98., 4032 e-mail: hortobagyi@med.unideb.hu)

\section{NOTA}

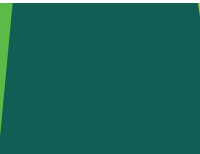

Új fejlesztés az egészségügyben dolgozók, tanulók részére!

\section{A magyar nyelvứ szakirodalmi keresőszolgáltatás}

Mi a NOTA?
Napivizit Orvosi Tudástár Alkalmazás
Mit tud a NOTA portál?
Megkönnyíti a magyar nyelvü
szakirodalmi források keresését.
Eszköztől függetlenül, akár
okostelefonról, a betegágy mellett
állva is használható.

\section{nota.hu}

\section{Miben kereshet a NOTA-val?}

Az Akadémiai Kiadó folyóirataiban: Orvosi Hetilap, Magyar Sebészet, Mentálhigiéné és Pszichoszomatika.

Más kiadók magyar nyelvű szakfolyóirataiban: pl. Lege Artis Medicinae, Hypertonia és Nephrologia, Ideggyógyászati Szemle.

A hatályos szakmai irányelvekben.

Magyar nyelvű kérdésekre adott angol nyelvű találatokban, a PubMeden.
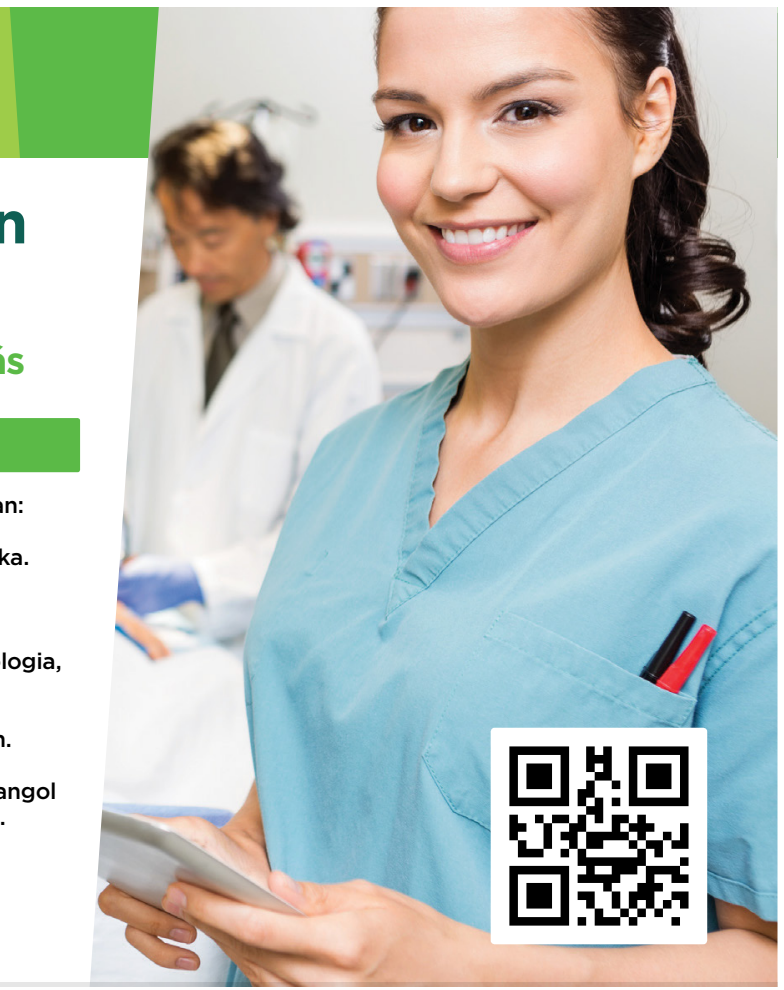

\section{Akadémiai Kiadó}

A Wolters Kluwer Csoport tagja

1117 Budapest, Prielle Kornélia u. 21-35. / Telefon: (1) 464-8246 www.akademiai.hu / www.akademiai.com

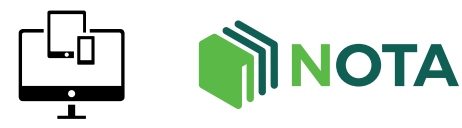

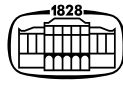

AKADÉMIAI KIADÓ 